2010

\title{
Sing On, Ntsikana: The Story of Christian Music among the Xhosa People of South Africa
}

Jonathan T. Knight

Cedarville University, jonathanknight87@gmail.com

Follow this and additional works at: https://digitalcommons.cedarville.edu/musicalofferings

Part of the Musicology Commons

DigitalCommons@Cedarville provides a publication platform for fully open access journals, which means that all articles are available on the Internet to all users immediately upon publication. However, the opinions and sentiments expressed by the authors of articles published in our journals do not necessarily indicate the endorsement or reflect the views of DigitalCommons@Cedarville, the Centennial Library, or Cedarville University and its employees. The authors are solely responsible for the content of their work. Please address questions to dc@cedarville.edu.

\section{Recommended Citation}

Knight, Jonathan T. (2010) "Sing On, Ntsikana: The Story of Christian Music among the Xhosa People of South Africa," Musical Offerings: Vol. 1 : No. 1 , Article 3.

DOI: $10.15385 /$ jmo.2010.1.1.3

Available at: https://digitalcommons.cedarville.edu/musicalofferings/vol1/iss1/3 


\title{
Sing On, Ntsikana: The Story of Christian Music among the Xhosa People of South Africa
}

\section{Document Type}

Article

\begin{abstract}
The Xhosa, an African people united by language and history, occupied a large portion of what is now eastern South Africa prior to the arrival of Europeans. After the arrival of Christianity through the Europeans, one of the earliest Xhosa converts, Ntsikana, was also the first Xhosa to compose music meant to worship their newfound Savior. Though this music in the traditional Xhosa style lay dormant for some time, enthusiastic Xhosa ministers in the past century have done much to learn from and expand upon the musical, spiritual legacy of Ntsikana. A unique blend of European and South African music has birthed among Xhosa Christians a distinct flavor of worship, which, though reflecting foreign influences, strongly retains indigenous traditions.
\end{abstract}

\section{Keywords}

Ntsikana, Xhosa, South Africa

\section{Creative Commons License}

(c) (i) (2)

This work is licensed under a Creative Commons Attribution-Noncommercial-No Derivative Works 3.0 License.

\section{Erratum}

Title on document should read Sing On, Ntsikana: The Story of Christian Music among the Xhosa People of South Africa 


\title{
Sing on, Ntsikana: The Story of Christian Music Among the Xhosa people of South Africa
}

\author{
Jonathan Knight \\ Cedarville University
}

7 The Xhosa, a people group united by language and history, occupied a large portion of what is now eastern South Africa prior to the arrival of Europeans. The Dutch were the first white men to touch South African's shores, and the British followed soon after. The forward progress of European forces caused the expulsion of the Xhosa from their native, ancestral land. But the seeds of Christianity were planted through contact with (mainly) English missionaries who told them the story of Jesus. One of the earliest converts to Christianity, Ntsikana, was also the first Xhosa to compose music meant to worship their newfound Savior. Though this music in the traditional Xhosa style lay dormant for some time, enthusiastic Xhosa ministers in the past century have done much to learn from and expand upon the musical, spiritual legacy of Ntsikana. A unique blend of European and South African music has birthed among Xhosa Christians a distinct flavor of worship, which, though reflecting foreign influences, strongly retains indigenous traditions.

In order to understand the Christian music that has been born in the Xhosa culture, one must first understand the historical events and cultural setting behind this group of people. The history of British colonization is a messy one, full of conquest and change, and riddled with injustice and atrocity. South Africa was no exception. The peoples of South Africa have suffered much under European rule. Nonetheless, this particular group showed a unique resilience in the face of European domination. There were certainly periods when their cultural voice was muffled, often because of missionaries who, tragically, held to the "gospel" of Western thought and culture as dogmatically as they did the Gospel of Christ.

In 1652, Dutch ships, sailing between Europe and the East Indies, were in need of a halfway harbor. The Dutch East India Company chose the southernmost tip of Africa as the location for such a haven. Soon a small number of employees had established themselves there, and by 1657 more Dutchmen began to arrive, building homesteads and farming the land (Elphick, 16).

Dutch farmers, referred to as Boers, slowly began settling to the east of the Cape colony. Surprisingly, they maintained relative peace with tribal groups who already occupied the frontier. As late as the mid-1700's, the Boers coexisted rather peaceably with the long-established Xhosa people, living in relative equality. The fact that the Dutch were far outnumbered certainly kept their colonial zeal in check. However, such an uneasy coexistence did bring its

Musical Offerings, vol. 1, no. 1, pp.21-31. ISSN 2167-3799

(C) 2010, Jonathan Knight, licensed under CC BY-NC-ND

(http://creativecommons.org/licenses/by-nc-nd/3.0/) 
challenges. Boer farmers, envious of the Xhosa's cattle and land, were known to steal Xhosa cattle. The Xhosa were far from innocent, often returning the favor in similar fashion. Outside of these small-scale incidents, however, stability was maintained. Leaders on both sides were quick to make amends for wrongs committed against the other. In fact, the two cultures functioned well together, in a haphazard way. Peires writes, "Poorer Xhosa became laborer-clients of rich Boers, and war criminals and political dissenters became the subjects of Xhosa chiefs.” In some instances, Xhosa chiefs actually made attempts to incorporate Boers into their culture (Peires, 53).

Except for pasture land and cattle, the Xhosa did not envy the Boers, since both groups functioned quite similarly to the other. Both the Boers and the Xhosa were agrarian peoples, and whatever technology the Europeans had held no special appeal to the Africans, who could perform the same tasks well enough without European ingenuity (Peires, 51).

But the peace did not last. The competition between the two groups for crops and pastureland, along with the European hunger for conquest, inevitably lead to large-scale conflict (Elphick, 69). War erupted on the frontier around 1779, as European forces (Dutch, soon followed by English) attempted to push the Xhosa further east, across the Fish River. Battles between 1779 and 1803 fell in favor of the Xhosa, whose numbers and war tactics rendered the Dutch horses and guns ineffective against them. These early victories gave them the confidence to continue fighting.

In 1806, the British made the choice to permanently claim South Africa as a colony for the motherland, and in 1811 the Xhosa resistance for their land came to a sudden end. The Xhosa did not recognize British sovereignty, and therefore needed to be removed. Governor Sir John Cradock communicated his strategy to Lieutenant-Colonel Graham, instructing him to "[Lay] waste their gardens and fields and in fact totally [remove] any object that could hold out to their chiefs an inducement to revisit the regained territory" (Peires, 53). The British had introduced Africa to "Total War," a concept completely foreign to the Xhosa, whose weapons of war were not even designed to be fatal (53).

Xhosa opposition was crushed in 1812. They were immediately expelled from their land to make way for white settlers. The land, their means of survival, their very life, had been taken. Their expulsion was particularly devastating due to their tradition that their land held mystical significance. Living in proximity to the burial grounds of their ancestors was believed to give supernatural benefits. Even the space where their cattle grazed was considered sacred. Leaving these lands would mean forsaking the "blessings and protection of the ancestors, the guardians of the land” (Elphick, 71).

Naturally, these shattering events caused an immediate leadership vacuum in Xhosa society. Peires comments that, "The expulsion created a set of problems 
which the Chiefs were unable to solve. Thus in the years immediately following 1812, political leadership passed from the hands of the chiefs into the hands of prophet-figures" (Peires, 54). It was in this time of crisis that two men, both claiming to speak on behalf of God, arose, attempting to address the grievous circumstances facing their people. Their messages were very different, as were their legacies. The two men were Nxele and Ntsikana.

These diviners, or prophets, attempted to reinterpret the problem of the white man in their land. They rose to positions of influence not because of "unfathomable magical powers but from the capacity to provide rational answers to pressing and very real questions. "Who are these white people? What do they want? What should be done about them" (Peires, 54)?

Understanding the impact that these two religious leaders had must be placed in the context of Xhosa spirituality. Xhosa's traditional religion, similar to many African worldviews, provided no distinction between the natural and supernatural. Natural circumstances, like rain, health, and fertility, were thought to be directly tied to supernatural dynamics. They believed that the unseen world could be manipulated by those who understood its mechanics (Peires, 55). Their idea of deity was impersonal, and contact with "it" was only sought in times of danger such as drought, disease, and war (Elphick, 69). Because they had no spiritual answers to the crisis at hand, namely the invasion of their land, the stage seemed perfectly sets for religious change.

Nxele and Ntsikana were both acquainted with Christian beliefs. An English missionary, J.T. Vanderkemp, was sent by the London Missionary Society to the Xhosa in 1799, in the midst of intense frontier warfare. Vanderkemp spent only one year among them, but much was accomplished during that time. (Elphick, 72) The Christian worldview which Vanderkemp brought was not wholly foreign to them, since Xhosa religion contains elements resembling Christian ideas of God, the Devil, and creation. But since they had no concept of resurrection and final judgment, Christianity explained death and thereby provided a missing link in their worldview (Peires, 56).

Nxele, born in the late eighteenth century, was introduced to Christianity early in his life, as he worked on a Boer farm. From this young age he also began displaying the "signs of being a diviner" (Elphick, 71). In the Xhosa culture, diviners, or witch doctors, were those with special connection with the supernatural world. This "calling” on a person would be evident by hysterical behavior, miraculous acts, and seeing visions, among other peculiar tendencies. Nxele began displaying such signs from an early age and in dramatic proportions (Peires, 56).

He began preaching in 1812, and because of his extensive contact with the Dutch, he spoke with the vocabulary of a missionary. He claimed to have seen Christ in a vision, in which Christ had rescued him from a fire. But his message was quite 
syncretistic. Elphick confirms this: "In addition to preaching orthodox biblical themes such as the fall, the flood, Christ's crucifixion and resurrection, and the concept of salvation versus eternal punishment, he spoke of Mdalidephu, creator of the deep, and his son Tayi, and claimed to have the same mother as Christ" (Elphick, 71).

At first he supported the European missionaries, viewing them as brothers and encouraging their presence among his people (Peires, 57). But with the continued advance of colonial domination, his message shifted to meet the occasion headon. After 1816, Nxele devoted his career to fighting against the English (Elphick, 72). Though his message quickly departed from the values of Christianity, he continued to incorporate Christian imagery. He attacked the British with a vengeance, having told his people he had the power to call up the spirits of their ancestors to fight with them. But he was eventually captured by the English, and died soon afterwards trying to escape. His followers, though relatively few, kept fighting, believing him to be immortal. He had taught them used apocalyptic imagery from Revelation, which he fused with the religious norms of his people. So they waited his "second coming," when he would bring them the salvation that he had promised (Elphick, 72).

Ntsikana, though his circumstances were very similar to Nxele's, left a very different legacy. He also experienced the signs of a diviner as a young man, seeing bright lights and falling into trances. The most dramatic event took place at a wedding ceremony. It was said that the moment that he began to dance following the ceremony, a mighty wind began to blow, and thunder and lightning came from nowhere. ${ }^{1}$ Ntsikana stopped dancing, and the storm immediately subsided. He again began to dance, and again the force of the wind was renewed. This was repeated several times, until Ntsikana left the wedding ceremony in astonishment (Ndletyana, 10).

Though his experience had nothing inherently Christian about it, he took it to be a calling not only toward the life of a diviner, but a message from God to embrace Christianity (Peires, 59). He refused to be baptized by the white men, but washed his own body of the "red ochre" which represented his culture (Ndletyana, 11). But similar to Nxele, he incorporated Christian teachings into a hybrid religion which he felt would best fit with the culture of his people (though not nearly as radical as his rival, Nxele). In fact, Ntsikana's teachings can be seen to move closer to Christianity as time went on, in direct contrast to Nxele (Peires, 59).

After receiving confirmation of his calling, Ntsikana began traveling extensively, preaching and establishing churches among his countrymen (Ndletyana, 11). His new message was in stark contrast to Nxele's call to revolt. Ntsikana taught that surrender to God was the answer to the problems his people faced; "complete submission to the will of God, where alone peace and protection were to be

\footnotetext{
${ }^{1}$ Throughout his life Ntsikana was known for his skill in dancing, singing, and poetry (Somniso, 137).
} 
found" (Peires, 60). Ntsikana was instrumental in spreading Christianity. He had a much greater influence than the missionaries in bringing the faith to his people. He also gave his people another gift, one that continues to impact them today, side-by-side with their faith: originally composed hymns.

At the time when Ntsikana began composing hymns, the idea of writing Christian music in an African musical idiom was unheard of. The European hymn was standard among the missionaries in South Africa, and from the beginning of the $19^{\text {th }}$ century this form, with its straight rhythms and four-part harmonies, was established by the missionaries as the standard for black church music. Following the tumultuous but transforming mission of Vanderkemp, the colonial government did allow other missionaries to go to the Xhosa, since the English hoped that the spread of Christianity would promote colonial interests (Elphick, 71).

In some ways this strategy proved effective. For early Xhosa converts to be considered genuine Christians, they were required to become members of the missionary Church, and encouraged and sometimes required to live at the mission station. This, it was hoped, would keep them from being tempted to "return to the bush.” In reality, becoming a follower of Christ meant being trained as a European in most aspect of culture, including music (Elphick, 319).

Missionaries encouraged the Xhosa to reform their ideas of music. This meant compartmentalizing the arts according to the European manner. Interestingly, the Xhosa had no abstract word for "music" in their language. Instead, they conceived of music in terms of the activities which it accompanied: the song, the dance, even the role of the singers. The Xhosa word $i$-culo was chosen by the missionaries to represent music in a European fashion. The missionaries' music was strictly diatonic, with careful avoidance of African rhythm. Their intent was to make a clear distinction between the cultural music making they were familiar with, which was an integral part of Xhosa community life, and the "Christian" music that was appropriate in church and school (Somniso, 132). Today i-culo retains the definition given by the English, and is defined in Kropf's Xhosa dictionary as “originally a short song, now a hymn” (Elphick, 319). It refers exclusively to “church or school singing performed without bodily movement” (320).

The European system was clearly inadequate for rendering the complexities of traditional Xhosa music effectively. However, some Western music did roughly resemble the established Xhosa tonal system, which was patterned on major triads. Two major triads a whole step apart (such as F and G) made up the fundamental harmonic movement in the Xhosa musical system. ${ }^{2}$

\footnotetext{
${ }^{2}$ This tonal system have developed based on the performing instrument of choice, the uhabi, or "musical bow." The overtones produced by this instrument (manipulated by the player) are the basis for their harmonic system. Elphick notes that, "the repeated use of major chords in the diatonic harmony of pieces like Handel's 'Hallelujah Chorus' was appealing to the Xhosa ears" (Elphick, 320).
} 
As the missionaries attempted to reshape the Xhosa concept of music, they immediately encountered significant difficulties. As the missionaries translated Protestant hymn texts directly into Xhosa, they failed to recognize the tonal nature of the language. ${ }^{3}$ Words in Xhosa have different meanings depending on changes in tone. In some Xhosa phrases, each word has its own individual tone! This is a linguistic characteristic shared by other nearby peoples, including the Zulu and Sotho. The pattern proceeds as follows: "the first phrase begins high, falls (through the steps of the word tone), and ends lower; the new phrase begins high again, but lower than the phrase before, then falls at its end, and so on” (Elphick, 321). Thus, the meaning of a translated hymns often proved to be humorous, at best, though more often they became totally absurd (Hawn, 108). For some reason early missionaries were either ignorant of this problem or chose to ignore it. Others sought to adjust selected syllables to alleviate the problem (Elphick, 321).

It does not appear that any missionaries at this time considered teaching the Xhosa people to write Christian music in their own tradition. Instead, it was Ntsikana who embarked into uncharted territory, composing songs for his congregation (Stone, 763). He personified his peoples' attempts not to be culturally whitewashed by Western influences. His first and greatest song, now known as the "Great Hymn," was composed the night following his conversion in 1814. He claimed to receive the Holy Spirit immediately, and stayed awake the entire night singing the chorus of his great composition (322). His contact with missionaries was minimal, so he "composed" in the only style he knew: the style of his people. It was not long before Xhosa choirs began performing the song, accompanied by dance (Somniso, 135). It has been passed on orally to this day (Stone, 763). In fact, his "Great Hymn" is "regarded as the summit achievement of Xhosa song" (Elphick, 322). It is also considered "the prototype of church music in a Traditional Xhosa style" (Hawn, 128). Here is a portion of the text of this hymn, "Ulo Tixo mkulu” as translated by David Dargie:

You are the Great God who dwells in the heavens.

You are the true shield.

You are the true fortress.

You are the true forest [of refuge].

It is you who dwells in the highest.

You created life, you created on high.

You are the creator creates the heavens.

You created the stars and the Pleiades.

A Star flashed forth, being us your message.

You created the blind - did you create them for a purpose?

\footnotetext{
3 These translated hymn texts were set to a variety of European melodies, and at times the combinations bordered on ridiculous. Hawn writes that, "totally absurd pairings of text and tunes sometimes resulted, such as singing the Latin hymn “Tantum Ergo' in Latin to the tune of 'My Darling Clementine.’” (108)
} 
The trumpet sounded, it has called for us.

You're the hunter who hunts souls.

You gather together flocks rejecting each other.

You are the Great Blanket with which we are clothed.

Your hands are wounded.

Your feet are wounded.

Your blood - why is it streaming?

Your blood was poured out for us.

Are we worthy of such a ransom?

Are we worthy to enter your homestead?

(Hawn, 134)

From the outset, this text reveals traditional Xhosa literary forms. For instance, rhyme in Xhosa songs consists in repeated words or phrases that give poetic as well as musical rhythm of the song. This can be seen in the first stanza, where the words, "You are" give continuity to this unit of text. The original word order actually brings this out with further clarity. Here are the first four lines of the first stanza in Xhosa:

Ulo Thixo oMkhulu, ngoseZulwini

Unguwena-wena Khaka leNyaniso

Unguwena-wena Nqaba yeNyaniso

Unguwena-wena Hlathi leNyaniso

(Somniso, 137)

The parallelism stands out clearly in the repetition of "Unguwena-wena," in lines one through three, and "leNyaniso" in lines two and four.

Rhythmically, this song employs the additive rhythm $3+3+2$, which is common in Xhosa music style. Clapping from the congregation reinforces the rhythm. The choir sings a basic three-voice cycle on the words, "Ahomna, homna, hom, homna, hom." The leader then sings out the stanzas above the pattern of the choir and accompaniment (Hawn, 133). Harmonically, it begins on an F Major chord, moves to a G Major chord, and ends on an F Major chord. It would therefore have been well-suited for accompaniment by the uhadi, (musical bow).

By the mid-1800s, the song was already widely known through oral transmission, and had been solidly established as a national song, and a freedom song for the Xhosa (Elphick, 323). It stands out significantly that Ntsikana's songs, like his theology, are complex hybrid of African, European, and Christian. Stone writes that Ntsikana's style "strikingly infuses protestant hymnody with the stateliness of Xhosa melody, harmony, and rhythm” (Stone, 763).

After Ntsikana's death in 1821, his followers, as well as some missionaries, set out to transcribe his hymns, which, though performed choirs everywhere, were 
not accessible apart from oral transmission. But transcriptions in English (Sol-Fa) singing style (with rigid rhythm) failed to do justice to the African harmonies. ${ }^{4}$ Nevertheless, the stiff musical tastes of the missionaries did not stop the Africans from keeping their music their own. Choirs continued to perform the hymn according to their culturally conditioned sense of harmony, a practice that has been termed "Afro-diatonic" music. African singers instinctively bend the diatonic scale to match their "sweeter" tonal system. They incorporated blue notes into their choral sound, adjusting the scale degrees as they feel the need. This instinctive harmonic freedom produces the sound that makes African choirs distinct. Each singer moves parallel to the melody, searching for the next court member by ear. Even in the absence of traditional rhythms, they refused to surrender their musical voice (Elphick 320).

In the late 1800's, a man named John Knox Bokwe played an important role in reinvigorating the musical legacy of Ntsikana, and adapting Xhosa music to the solfege system. His parents and grandparents were faithful disciples of Ntsikana, and he was the first Xhosa to be ordained, serving as a choirmaster in the Presbyterian church (Stone, 763). Bokwe spent much time studying Ntsikana's musical works, and published a series of transcriptions of Ntsikana's hymns between 1878 and 1914 (Elphick, 323).

Bokwe's "revival” of Ntsikana's work proved to be the first in a growing tradition of Christian Xhosa songwriters. The Catholic Church has been the most notable example of a Christian group to encourage and facilitate worship in an African style. The papal encyclical Musicae sacrae in 1955 first "encouraged missionaries to promote local music for use in worship." South Africa was among the first African nations to begin widespread usage of culturally traditional music in church worship $^{5}$ (Elphick, 321). With the unique influence of Ntsikana in South Africa, this comes as no surprise!

In the 1960s, Catholic missionaries began actively assisting the Xhosa (and other tribes) in composing liturgical music in traditional styles. This shift took place following the historic Vatican II, 1962-1965, which opened the doors for indigenous liturgies. These were days of "encouragement in creativity and experimentation” (Hawn, 108).

In 1965, prolific Xhosa composer (in western style) Benjamin Peter John Tyamzashe was commissioned by Fritz Lobinger and Oswalt Hirmer, members of the Lumko Missiological Institute, to write a liturgical piece in Xhosa style. Tyamzashe had not considered composing music in his native style before, so he

\footnotetext{
${ }^{4}$ The Sol-Fa (solfege) method of singing was developed by a British educator named John Curwen.

${ }^{5}$ The use of African musical idioms today is most notably seen in the Zionist churches of South Africa, the first of which were planted in the early 1900. This "denomination" was formed with the specific intent of resisting white religious domination and worshiping in an African way. (Peires, 136; Elphick 323)
} 
turned to Ntsikana's hymns for inspiration (Hawn, 108). The result was his "Gloria," the first original piece of Christian Xhosa music written in traditional style since the death of Ntsikana over 140 years earlier (Elphick, 321).

David Dargie, a Catholic missionary, was next to pick up the baton in the growing momentum of Xhosa composition. At first glance, a white priest would not appear to be an effective candidate for promoting ethnic African music. But, as a third generation South African and outstanding musicologist, Dargie has proved to be a central figure in training the Xhosa in composition and performance of their native music, in both liturgical and cultural life (Hawn, 108). He himself is an accomplished composer and performer of traditional Xhosa music, and between 1977 and 1986 he organized a number of composition workshops for local Xhosa pastors. At these seminars, appropriate liturgical texts were suggested, musicians were brought in for demonstration and inspiration, and a panel of ministers developed the music together. At the ends of the seminar, recording of their work were produced, for pastors to take back to their congregations. In this way clergy and congregations could fully embrace their African heritage of oral tradition in learning and performing liturgical music, instead of remaining dependent on Western notation to learn the songs.

These slow steps of musical progress all took place under the crushing hand of "apartheid" policy under British rule. The system legislated segregation and suppression of Africans until it dissolved in 1998. Since then, "choral singing, clapping, body movement, and even drumming is entering worship in the mainline churches more and more often, most of all in those churches in areas where the spirit of resistance to apartheid had been strongest” (Elphick, 325). Western musical elements certainly maintain their presence through strictly notated music, “to be performed under a conductor's baton by uniformly robed choirs” (Elphick, 325). But many choirs continue to interpret music with a strong African flair.

The resistance that the Xhosa demonstrated in the face of cultural oppression is a microcosm, revealing a larger movement among Africans to claim back their traditional heritage. Though this is a messy process in which the tenants of Christianity are sometimes compromised, the pendulum has thankfully swung away from the cultural oppression initiated by colonial powers. And the Xhosa, who continue to be strengthened by the inspiring hymns of Ntsikana, refuse to let their musical voice be stopped. Although highly influenced by European and Christian traditions, Xhosa music today remains, at its core, African. 


\section{Bibliography}

Achebe, Chinua. Things Fall Apart. Johannesburg, South Africa: Heinemann Publishers, 1958.

Corbitt, J. Nathan. The Sound of the Harvest: Music's Mission in Church and Culture. Grand Rapids, MI: Baker Books, 1998.

Elphick, Richard, and Rodney Davenport, eds. Christianity in South Africa: A Political, Social, and Cultural History. South Africa: David Phillip Publishers, 1997.

Hawn, C. Michael. Gather Into One: Praying and Singing Globally. Grand Rapids, MI: W.B. Eerdmans Publishers, 2003.

Lucia, Christine. The World of South African Music: A Reader. Cambridge, UK: Cambridge Scholars Press, 2005.

Ndletyana, Mcebisi, ed. African Intellectuals in 19th and Early 20th Century South Africa. HSRC (Human Sciences Research Council) Press: South Africa, 2008.

http://www.hsrcpress.ac.za/product.php?productid=2215\&freedownload= $\underline{1}$

Pauls, Elizabeth, and Amy Tikkanen. “Xhosa” Encyclopcedia Britannica.

Encyclopcedia Britannica Online:

http://www.britannica.com/EBchecked/topic/650753/Xhosa\# (Accessed December 9, 2009).

Peires, J. B. "Nxele, Ntsikana and the Origins of the Xhosa Religious Reaction.” Journal of African History 20, 1 (1979): 51-61. http://stmarys.ca/ wmills/course322/Nxele_Ntsikana.pdf. (Accessed November 4, 2009).

Sachs, W.L. The Transformation of Anglicanism. Cambridge, UK: Cambridge University Press, 1993.

Somniso, M. M. "Echoes of Orality in Christian Xhosa Songs." Literator 26, no. 3 (November 2005): 131-145. Humanities International Complete, EBSCOhost http://search.ebscohost.com/login.aspx?direct=true\&db=hlh\&AN=231909

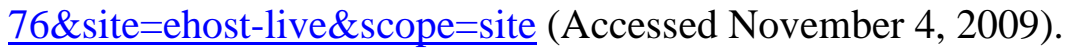

Stone, Ruth M, ed. The Garland Encyclopedia of World Music. New York: Garland, 2000. 
Wainwright, Geoffrey, and K. Tucker, eds. The Oxford History of Christian Worship. Oxford; New York: Oxford University Press, 2006. 